University of Tennessee Law

Legal Scholarship Repository: A Service of the Joel A. Katz Library

UTK Law Faculty Publications

$9-2016$

Nudging Entrepreneurs into Noncompliance: Why Does Nevada

Have so Many Benefit Corporations? [Blog Post]

Eric Franklin Amarante

Follow this and additional works at: https://ir.law.utk.edu/utklaw_facpubs

Part of the Law Commons 


\section{Nudging entrepreneurs into noncompliance: Why does Nevada have so many benefit corporations?}

\section{Eric Franklin ${ }^{1}$}

For most new businesses, Delaware is the default state of incorporation. Many states have tried to unseat Delaware as the preferred destination for business formation, offering low (or no) corporate taxes, administrative ease in fulfilling corporate formalities, or favorable business laws. Nevada is one of these states, openly marketing itself as the Delaware of the West. ${ }^{2}$ However, despite its best efforts, Nevada still lags behind Delaware on business formations. In 2014, for example, Nevada had 57,644 new entity filings, ${ }^{3}$ which is just slightly more than one quarter of Delaware's 168,966 new entity filings for the same period. ${ }^{4}$

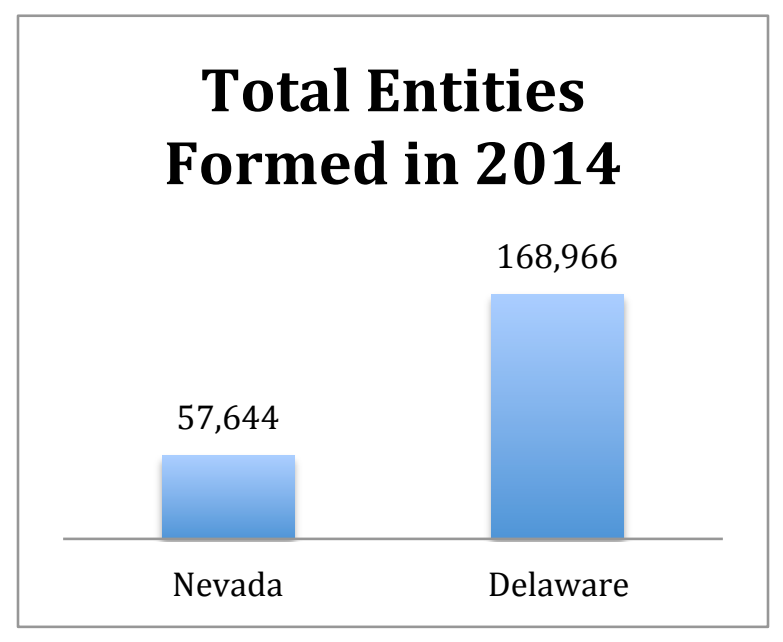

Given these data, it appears that Nevada's bid to become the leader in business formations has failed. However, there is one area where Nevada has bested Delaware: formation of benefit corporations. ${ }^{5}$ In 2014, there were 158 benefit corporations formed in Delaware, ${ }^{6}$ while Nevada had 697 benefit corporations formed in the same period. ${ }^{7}$

\footnotetext{
${ }^{1}$ Associate Professor of Law and Director of the Small Business and Nonprofit Legal Clinic, William S. Boyd School of Law, University of Nevada, Las Vegas. The author would like to thank Andrew Martineau and Christopher Kelly for their research assistance and Adam Ellis and Emily Haws for their helpful comments.

2 "Nevada has, perhaps, been the most aggressive challenger of Delaware, loosening its laws to protect managers (directors and officers) even more than Delaware and advertising the benefits of Nevada corporate law heavily."

3 See Nevada Secretary of State 2013-2014 Biennial Report, available at http://nvsos.gov/sos/home/showdocument?id=3485.

4 See Delaware Division of Corporations 2014 Annual Report, available at http://corp.delaware.gov/Corporations_2014\%20Annual\%20Report.pdf (Delaware Annual Report). These numbers are even starker when one considers that Nevada has a population of roughly three times that of Delaware (2,890,848 and 945,934, respectively, according to 2015 U.S. Census estimates).

${ }^{5} \mathrm{~A}$ benefit corporation is a relatively new for-profit entity form that explicitly permits the organization to use corporate assets in a socially beneficial manner.

${ }^{6}$ See Delaware Annual Report.

${ }^{7}$ Data received from Nevada Secretary of State, on file with the author.
} 


\section{Benefit Corporations Formed in 2014}

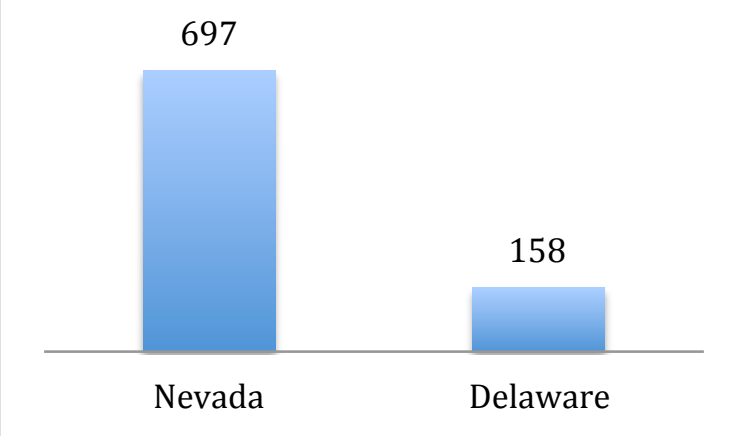

Thus, despite the fact that there were about three times as many businesses formed in Delaware than in Nevada in 2014, Nevada had more than four times the number of benefit corporation formations. What accounts for this discrepancy? Are Nevada entrepreneurs particularly socially conscious? Does Nevada law provide more protection for businesses that look beyond the bottom line? Has the Delaware of the West moniker begun to take hold among the entrepreneurs interested in corporate social responsibility?

It turns out that the answer is much more mundane. The startling number of benefit corporations formed in Nevada is due to the Nevada Secretary of State's website design. ${ }^{8}$ As this blog post will show, the architecture of the website inadvertently encourages the formation of benefit corporations.

To form a corporation in Nevada, an entrepreneur uses SilverFlume, ${ }^{9}$ a user-friendly Secretary of State website that walks the entrepreneur through an online formation process in a matter of minutes. After logging in and choosing "Form a corporation," an entrepreneur is faced with the following webpage:

\footnotetext{
${ }^{8}$ J. Haskell Murray, The Social Enterprise Law Market, 75 Maryland L. Rev. 541, 581 (2016) ("Nevada is in the lead [for benefit corporations] currently, but may have been boosted by the inclusion of a benefit corporation check box on the state form, which incorporators may or may not have fully understood.").

${ }^{9}$ SilverFlume: Nevada's Business Portal, https://www.nvsilverflume.gov/home.
} 


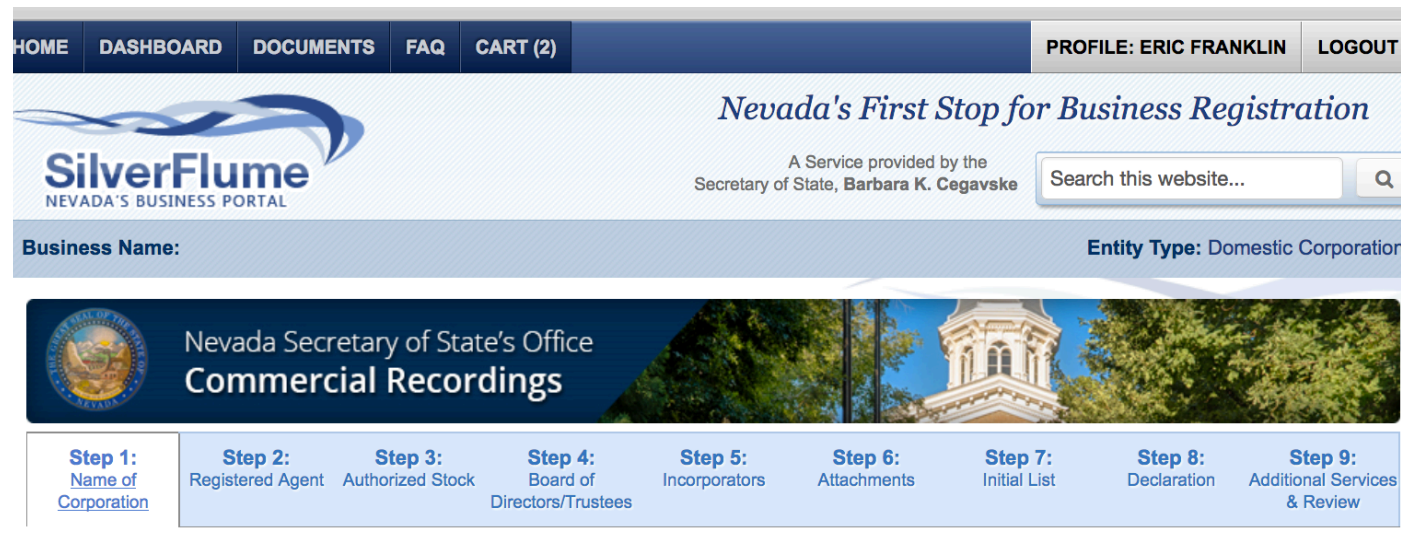

Enter your Corporation name below. The system will verify you may use the name in your filing. Need help with name availability?

**UPON COMPLETING YOUR FILING, THE INFORMATION WILL BE TRANSLATED TO ALL CAPITAL LETTERS. **

As you proceed, your filing *auto-saves* to your Dashboard for later access.

$\square$ I already have a reserved name

* Name

$$
\text { Please omit Entity Ending }
$$

* Entity Suffix

English Translation

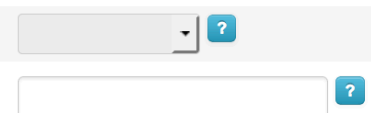

(If submitting a name in a foreign language)

* Is this entity a "Benefit $\bigcirc$ Yes $\bigcirc$ No ?

Corporation"?

Stating your business entity's purpose is optional at this stage, but it may require regulatory approval further in the process.

The purpose of the Corporation

shall be:

Any Legal Purpose

-

Cancel

Note that on the very first page, the website asks if the entity is a "Benefit Corporation." This is the first required question after the corporation's name and suffix. If the entrepreneur clicks on the question mark beside the prompt, a pop-up window provides the following information:

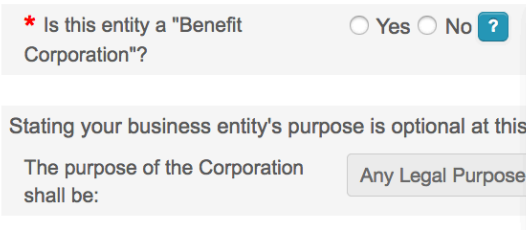

Cancel
A "Benefit Corporation" means a corporation organized under chapter 78 or 78 A of NRS, NRS 81.010 to 81.160 , inclusive, or chapter 89 of NRS that has elected to become subject to this chapter and whose status as a benefit corporation has not been terminated pursuant to this chapter. Questions? See the FAQ link at top or call the Secretary of State's Office at (775) 684-5708 option 9 .

If the entrepreneur selects "Yes," he or she is asked to "Explain the purpose of the corporation." An entrepreneur might put anything in this section, and there is no mechanism to ensure that the purpose is socially beneficial. An entrepreneur might simply enter "run a mechanic shop" or "sell coffee." The website makes no distinction between a socially beneficial purpose and a 
traditional for-profit purpose, and there is therefore no notice to the entrepreneur that a benefit corporation is supposed to create "a material positive impact on society and the environment."10 After this page, the website ushers the entrepreneur through the balance of the formation process, and the benefit corporation question is never again broached.

By presenting the choice in this manner, the Nevada Secretary of State has inadvertently encouraged the formation of benefit corporations. Neither the prompt nor the pop-up window adequately inform the entrepreneur of what, precisely, a benefit corporation is. All the entrepreneur sees is the following question: "Is this entity a 'Benefit Corporation'?" Without adequate legal counsel, there is no reason for an entrepreneur to recognize the consequences of this decision.

It is therefore not surprising that Nevada can boast the formation of so many benefit corporations. It is likely that the entrepreneurs have no idea what they are choosing. They are presented with the option of either being or not being a "benefit" corporation. Is it any wonder that many entrepreneurs have unwittingly chosen yes? Who wouldn't want to be a benefit corporation, even if they don't know what it means?

One might reasonably ask how we can be sure these decisions were mistakes. Although it is unlikely, certainly there is some chance that Nevada has a peculiarly socially conscious entrepreneurial community. However, preliminary research reveals that the vast majority of benefit corporations were probably formed unintentionally. For example, of the 697 benefit corporations formed in Nevada in 2014, only one entity has posted the required annual benefit report on its website. ${ }^{11}$

Delaware takes a very different approach. Benefit corporations are presented as an entity option in the same list as traditional corporations, nonprofit corporations, LLC, and partnerships. Each entity requires a completely separate set of forms. Thus, an entrepreneur forming an entity in Delaware must make a separate decision to form a benefit corporation. The entrepreneur is not, as in Nevada, asked in an offhand manner if the corporation being formed is a benefit corporation. In Delaware, an entrepreneur is apprised of the fact that the benefit corporation is a separate entity, with consequences and responsibilities that may be different from traditional corporations.

The Nevada Secretary of State website is performing a disservice to entrepreneurs. By inadvertently persuading entrepreneurs to form benefit corporations, the Secretary of State is setting the entities up for failure. Without proper notice of the expectations attendant to being a benefit corporation, such entrepreneurs will undoubtedly fail to fulfill their statutory responsibilities.

\footnotetext{
${ }^{10}$ NRS 78B.040

${ }^{11}$ According to NRS 78B.170, a benefit corporation must post its annual benefit reports on the entity's website. The results of this research are on file with the author and will be presented in a future article.
} 